\title{
PENDIDIKAN ANAK PERSPEKTIF SUFISTIK DALAM PANDANGAN IBNU QAYYIM AL-JAUZIYAH
}

\author{
Anggi Anggraeni Islami \\ UIN Sunan Gunung Djati Bandung \\ Email: anggianggraeni96@gmail.com \\ Rifki Rosyad \\ UIN Sunan Gunung Djati Bandung \\ Email: rifkirosyad@uinsgd.ac.id
}

\begin{abstract}
Abstrak
Pendidikan yang diterima anak sejak masa pertumbuhan dari orangtuanya akan sangat berpengaruh terhadap kualitas akhlak yang akan dimilikinya. Pendidikan pertama berawal dari lingkungan keluarga. Oleh karena itu, perhatian orangtua sangatlah penting sebagai bentuk tanggungjawabnya dalam memberikan pendidikan, terutama terkait pendidikan keimanan dan akhlak. 'Lembaga' untuk mempertahankan dan membentuk insan yang berakhlakul karimah adalah keluarga. Strategi untuk menjadikan keluarga tetap dapat menjaga ketahanan akhlak mulia di kalangan para sufi khususnya pendidikan anak juga mendapatkan perhatian besar. Salah satu di antara tokoh sufi kontemporer, seorang ulama besar sekaligus reformis pemikir Islam yaitu Ibn Qayyim Al-Jauziyah yang sangat memerhatikan pendidikan anak baik pada masa prenatal (sejak dalam kandungan) maupun pada masa postnatal (pasca dilahirkan). Tulisan ini berusaha menjawab pertanyaan bagaimana metode sufistik Ibn Qayyim AlJauziyah dalam mendidik anak. Metode penelitian yang digunakan adalah content analysis terhadap karya-karya Ibn Qayyim khususnya dalam kitab Tuhfatul Maudud bi Ahkam Al-Mulud.
\end{abstract}

Kata Kunci:

Pendidikan Anak; Sufistik; Ibnu Qayyim Al-Jauziyah

DOI: http://dx.doi.org/10.15575/saq.v4i2.7587

Received: 2020-01-25; Accepted: 2020-01-26; Published: 2020-01-29

\section{A. PENDAHULUAN}

Seorang anak merupakan salah satu amanah yang dianugerahkan Allah Swt. kepada kedua orangtuanya. Dengan begitu, diperlukan adanya rasa tanggungjawab dari orangtuanya yang sangat berperan penting dalam hal mendidik anak ${ }^{1}$ yaitu dengan menanamkan sedemikian rupa akhlak yang baik, ${ }^{2}$ sehingga dengan perlakuan yang baik seperti itu berarti orangtua mampu menunaikan amanah tersebut. Karena salah satu bentuk tertunaikannya amanah orangtua yang diberkahi seorang anak ialah dengan

\footnotetext{
${ }^{1}$ Toto Tasmara, Kecerdasan Ruhaniah (Jakarta: Gema Insani Press, 2003). 3.

${ }^{2}$ Abu Muhammad Iqbal, Konsep Pemikiran Al-Ghazali Tentang Pendidikan (Madiun, Jawa Timur: Jaya Star Nine, 2013)., 79
}

memberikan pendidikan yang baik sampai si anak mempunyai akhlak yang mulia. ${ }^{3}$ Yang nantinya, ketika masa pertumbuhan si anak diajarkan agar berkepribadian serta berperilaku mulia dan dibimbing supaya dapat mengenal Allah Swt. hingga memasuki usia dewasa ia akan mendapatkan ketentraman serta kebahagiaan yang abadi.

Setiap manusia sejak dalam kandungan (diciptakan Allah Swt.) telah dibekali dengan berbagai potensi yang sering dikenal dengan fitrah. ${ }^{4}$ Potensi tersebut salah satunya berupa wawasan dan pengetahuan untuk dapat memahami setiap keadaan yang dialami dan peroalan yang dihadapi karena

\footnotetext{
${ }^{3}$ Ibrahim Amini, Asupan Ilahi agar tak salah mendidik amanat-Nya 3 (jakarta: Nur Al-Huda, 2011)., 17 4 Iqbal, Konsep Pemikiran Al-Ghazali Tentang
} Pendidikan., 63 
pada dasarnya manusia diciptakan atas dasar keimanan kepada-Nya. ${ }^{5}$ Menurut sebagian pendapat yang mengacu pada hadis, ${ }^{6}$ dijelaskan bahwa manusia dari awal kelahirannya sudah tersistem sebagai seorang yang muslim dengan bentuk potensi hakiki keberadaan-Nya yaitu Islam (menerima dan menjalankan agama) ${ }^{7}$. Hal itu disebabkan karena dalam hadis tersebut tidak digambarkan secara jelas peran dan fungsi orang tua untuk membentuk keagamaan anaknya yang muslim.

Akan tetapi menurut Dr. Shalih Adhyamah yang dikutip oleh Jalaludin Rahmat menyebutkan bahwa pembawaan dasar manusia bukan hanya fitrah saja, melainkan termasuk pula sebagai pembawaan dasar manusia ialah gharizah yaitu pembawaan dasar manusia yang memiliki sifat seperti sifat kebinatangan. Dengan demikian, manusia tidak akan selamanya berada pada fitrahnya yang suci (mengenal Allah). Karena manusia pun diciptakan dilengkapi dengan nafsu yang selalu mendorongnya untuk berbuat maksiat (lupa pada Allah Swt.). Tapi bukan berarti fitrah tersebut hilang begitu saja, karena menurut Jalaludin, fitrah tidak akan pernah hilang dalam diri manusia, akan tetapi fitrah akan melemah jika kita terbiasa melalukan perbuatan yang Allah Swt. tidak ridha atas perbuatan tersebut (maksiat). ${ }^{8}$

Pada hakikatnya, seorang anak yang akan menjadi generasi unggul, mereka tidak akan mampu berkembang dengan sendirinya. Hal itu disebabkan karena

\footnotetext{
${ }^{5}$ M. Quraish Shihab, Tafsir Al-Mishbah (Jakarta Pusat: Lentera Hati, 2012)., 208

6 "Sesungguhnya Abu Hurairoh berkata, 'telah bersabda Rasulullah Saw. 'tidak seorang anakpun dilahirkan kecuali dalam keadaan fitrah, maka kedua orangtuanyalah yang menyebabkannya menjadi yahudi, nasrani, dan majusi. Sebagaimana hewan juga dilahirkan menjadi hewan. Adakah kamu ketahui ada kekurangan pada fitrah itu?".

${ }^{7}$ Baharuddin, Aktualisasi Psikologi Islami (Yogyakarta: Pustaka Pelajar, 2011), 36.

8 Jalaludin Rakhmat, Reformasi Sufistik (Bandung: Pustaka Hidayah, 1999), 131-132.
}

sejak lahir manusia dalam keadaan yang kosong pikir dan lemah fisik, artinya ia tidak mengetahui apapun dan tak berdaya. ${ }^{9}$

Mereka membutuhkan seseorang yang akan membimbing dan mengajarinya serta memerlukan kondisi lingkungan subur yang akan mendorong anak dalam berbuat baik. ${ }^{10}$ Dengan demikian, peran orangtualah sebagai lingkungan pertama yang dikenali anak juga sebagai madrasah pertama bagi anak yang berhak dan bertanggungjawab terhadap masa depan anak-anaknya. Tugas utama orangtua ialah bagaimana orangtua memperlakukan anaknya dengan memberikan pendidikan (mendidik) sejak lahir supaya kesucian (fitrah) anak dapat berkembangan secara baik dan maksimal rohani ataupun jasmani. ${ }^{11}$

Tugas orangtua sebenarnya cukup berat karena harus mengenalkan Allah Swt. serta menanamkan sedemikian rupa akhlak yang baik dan mulia dalam diri anak. ${ }^{12}$ Imam Sajjad mengatakan bahwa orangtua memiliki kewajiban terhadap anaknya, karena orang tua telah diberikan amanah oleh Allah SWT untuk membimbing dan mengajarkan akhlak mulia dengan tujuan anak dapat mengenal Allah dan selalu mentaati serta menjalankan segala perintahnya dengan kesungguhan dan keihlasan. ${ }^{13}$

Dengan begitu pada masa si anak mencapai usia dewasa ia akan terbiasa dengan kebiasaan baik serta kelak mereka

\footnotetext{
${ }^{9}$ QS. An-Nisa. 28 "Allah hendak memberikan keringanan kepadamu karena manusia diciptakan (bersifat) lemah" dan QS. An-Nahl :78 "Dan Allah mengeluarkan kamu dari perut ibumu dalam keadaan tidak mengetahui sesuatu pun, dan dia memberimu pendengaran, penglihatan, dan hati nurani agar kamu bersyukur",

${ }^{10}$ Muhammad Abdullah, "Pendidikan Prenatal: Telaah Pemikiran Ibn Qayyim Al-Jauziyah dalam Kitab Tuhfah Al-Maudud bi Ahkam Al-Maulud dan Relevansinya dengan Pendidikan Islam," al-Murabbi 2, no. 2 (2017)., 344

${ }^{11}$ Reza Farhadian, Menjadi Orangtua Pendidik (Jakarta: Al-Huda, 2005), 59.

12 Iqbal, Konsep Pemikiran Al-Ghazali Tentang Pendidikan, 79.

${ }^{13}$ Ibrahim Amini, Asupan Ilahi Agar Tak Salah Mendidik Amanat-Nya 3 (jakarta: Nur Al-Huda, 2011), 17.
} 
akan mampu menjalankan tanggungjawab sebagai pribadi maupun sebagai bagian dari lingkungan sosial serta dapat menjalankan kehidupan di tengah masyarakat dengan baik, karena hal itu sudah ditanamkan sejak usia dini (masa pertumbuhan).

Akhlak sebagai salahsatu pilar dalam ilmu tasawuf untuk membersihkan diri, sedangkan untuk mencapai akhlak mulia itu sangatlah tidak mudah. Semua itu akan sangat bergantung pada pola pendidikan yang diberikan orangtua sebagai agen sosialisasi pertama pada anaknya serta kondisi lingkungan yang mewarnainya. ${ }^{14}$

Mengingat betapa urgennya peran orangtua dalam pendidikan (mendidik) anaknya seperti pandangan Al-Ghazali yang menganggap urusan sangat penting dan kuat keperluannya dalam hal pendidikan anak. Beliau mengatakan bahwa qalbu seorang anak masih suci bagaikan mutiara indah, halus nan suci. Pada masa itu, setiap bentuk ajaran yang diterimanya (apapun yang dilihat dan didengar) akan dengan mudahnya terpatri dalam jiwa anak yang nanti akan menjadi kebiasaan yang akan dilakukan anak di masa dewasanya. Jika yang diterimanya ialah kebaikan maka si anak akan berada pada jalur kebaikan, sebaliknya, jika yang diterimanya ialah ajaran yang sia-sia tanpa adanya sentuhan kebaikan niscaya kelak si anak akan celaka dan merasakan kebinasaan dalam hidupnya. ${ }^{15}$

Selain Al-Ghazali, salah satu intelektual muslim juga sebagai ulama tersohor serta reformis pemikir Islam pada abad ke-13 adalah Ibn Qayyim AlJauziyah, ia sangat memperhatikan pendidikan usia dini, bahkan sejak masa prenatal (masa di dalam kandungan) serta pada masa postnatal (pasca dilahirkan).

Dari latar belakang tersebut, penulis ingin mengungkap lebih jauh mengenai

14 Rosihon Anwar, Akhlak Tasawuf (Bandung: CV Pustaka Setia, 2010), 13.

${ }^{15}$ Al-Ghazali, Ihya Ulumuddin (Jakarta: Republika Penerbit, 2012), 259-260. bagaimana para sufi membangun pembinaan akhlak mulia serta mempertahankan perilaku baik tersebut dengan cara mendidik agar dapat mencerdaskan anak serta membina akhlak dan juga mencontohkannya

Menelaan konsep Ibnu Qayyim AlJauziyah dalam karyanya yang berjudul "Tuhfatul Maudud fi Ahkam al-Maulud (Hanya untukmu Anakku)" ia menjelaskan menerangkan secara lengkap bahwa hukumhukum tentang anak dari sejak di dalam kandungan hingga dewasa serta kiat-kiat mengurus anak agar kepribadian yang mulia serta pertumbuhan fisik anak maksimal.

\section{B. HASIL DAN PEMBAHASAN}

1. Biografi Ibn Qayyim Al-Jauziyah

Abu Abdullah Syamsuddin Muhammad bin Abu Bakar bin Ayyub bin Sa'ad Ibn Hariz bin Makkiy Zayn al-Din ${ }^{16}$ az-Zur'i adDimasyqi ${ }^{17}$ biasa dikenal dengan sebutan Ibnu Qayyim Al-Jauziyah dan julukannya Syamsuddin dan kun-yahnya Abu Abdillah. dilahirkan pada tanggal 7 Shafar $691 \mathrm{H}$ sedang dalam kelender Hijriah adalah 29 Januari tahun 1292 M di Azra. Ayahnya bernama Abu Bakr Ibn Ayyub al-Zur'iy. Ayahnya adalah seorang pimpinan, yang bertanggung jawab sebagai pengurus, dan qayyum (tonggak) di madrasah AlJauziyah $^{18}$ sekaligus berprofesi menjadi guru dan mengajarkan ilmu yang dikuasainya. ${ }^{19}$ Ibnu Qayyim berasal dari keluarga berilmu, terhormat, serta mapan secara ekonomis ${ }^{20}$ serta diwarnai dan dinaungi oleh nuansa ilmu pengetahuan,

16 Muhaemin, "Konsep Pendidikan Ibn Qayyim AlJauziyah," jurnal Ulul Albab, vol 13 (2011), 7.

17 Ibnu Qayyim Al-Jauziyah, Hanya Untukmu Anakku, Panduan Lengkap Pendidikan Anak Sejak dalam kandungan hingga dewasa terj. Tuhfatul Maudud bi Ahkam Maulud (Jakarta: Pustaka Imam Asy Syafi'i, 2012), 13.

18 Arikhah, "Reaktualisasi Pemikiran Ibn Qayyim AlJauziyyah dalam Pengembangan Tasawuf" at-Taqaddum 8, no. 1 (2016), 76.

19 Wawan Hernawan, "Posisi Ruh Dalam Realitas Menurut Ibnu Qayyim Al-Jauziyah," Syifa al-Qulub, 1 (2017), 78 .

20 Muhaemin, "Konsep Pendidikan Ibn Qayyim AlJauziyah.", 8 
ketaqwaan, kemuliaan, kewara'an dan kedamaian. $^{21}$ Di bawah asuhan ayahnya sendiri yang dikenal sebagai orang yang shalih dan karismatik Ibnu Qayyim AlJauziyah dibesarkan di tengah keluarga yang religius dan memiliki banyak keutamaan. ${ }^{22}$

Sejak kecil, Ibnu Qayyim Al-Jauziyah dikenal sangat tekun dalam cari ilmu. Beliau lakukan dengan penuh kesungguhan dan kegigihan dalam melakukan penelitian dan pengkajian, ${ }^{23}$ sehingga tidak jarang Ia pun ikut belajar bersama orang-orang yang jauh lebih dewasa darinya. ${ }^{24}$ Sebelum Ia menyerap ilmu dari ulama terkemuka semasa hidupnya. Pertama kali, beliau menuntut ilmu kepada ayahnya sendiri ${ }^{25}$ yang sangat mahir dan sangat menguasai ilmu faraidh (ilmu waris). ${ }^{26}$ Sebelum usianya genap sembilan tahun Ibnu Qayyim sudah pandai berbahasa Arab dan menguasai ilmunya, karena di usianya yang masih belia Ibnu Qayyim sudah hampir mematangkan ilmu Bahasa Arab dan ilmu nahwu kepada gurunya bernama Syaikh Abu al-Fath alBa'labakki. ${ }^{27}$ Barulah beliau melanjutkan menuntut ilmu di madrasah kepada

${ }^{21}$ Arikhah, "Reaktualisasi Pemikiran Ibn Qayyim AlJauziyyah dalam Pengembangan Tasawuf.", 76

${ }^{22}$ Rusdaya Basri, "Ibnu Qayyim Al-Jauziyah tentang Pengaruh Perubahan Sosial," Al-Manahij IX, no. 2 (2015), 195.

23 Al-Jauziyah, Hanya Untukmu Anakku, Panduan lengkap pendidikan anak sejak dalam kandungan hingga dewasa terj. Tuhfatul maudud bi ahkam maulud), 14

${ }^{24}$ Hernawan, "Posisi Ruh Dalam Realitas Menurut Inu Qayim Al-Jauziyah", 79.

${ }_{25}^{25}$ Sebagai guru pertama

${ }^{26}$ Muhammad Abdullah, "Pendidikan Prenatal: Telaah Pemikiran Ibn Qayyim Al-Jauziyah dalam Kitab Tuhfah Al-Maudud bi Ahkam Al-Maulud dan Relevansinya dengan Pendidikan Islam," al-Murabbi 2, no. 2 (2017), 347.

${ }^{27}$ Kitab yang dipelajari ialah kitab Alfiyah Ibnu Malik dan semisalnya.

Lihat Basri, "Ibnu Qayyim Al-Jauziyah tentang Pengaruh Perubahan Sosial.”, 195 beberapa ulama terkemuka yang hidup di masanya $^{28}$ dengan berbagai bidang ilmu. ${ }^{29}$

Ketika kondisi Islam pada saat itu berada pada tingkat keterpurukan dengan timbulnya perselisihan-perselisihan yang semakin memperburuk kondisi serta melalaikan kaum muslimin. ${ }^{30}$ Kondisi demikian membuat orang-orang tidak mau untuk mencari ilmu serta menjadikan bakatbakat pun menjadi beku sehingga tidak mampu melahirkan ide-ide cemerlang untuk dilakukan pembaharuan. Akan tetapi, di tengah kondisi masyarakat seperti itu, Ibnu Qayyim sebagai sosok remaja muslim yang sangat peduli terhadap kondisi umat, muncul dengan harapan ingin meluruskan setiap kekeliruan yang terjadi, menyelamatkan mereka dari kegelapan perselisihan, dan ingin membangkitkan mereka dari keterpurukan. Semua itu ingin dilakukannya supaya umat Islam sampai pada puncak tujuan termulia. Kembali pada jalan lurus dan terang yang ditempuh kaum Salafush Shalih di bawah cahaya agama dengan mengikuti petunjuk Alquran. ${ }^{31}$ Beliau menganggap bahwa madzhab salaf adalah madzhab yang paling selamat (paling mengetahui dan bijaksana). Beliau ingin membawa orang-orang Islam pada keluwesan berfikir, menjauhi taqlid, serta mematahkan upaya orang-orang yang mempermainkan agama. Pemahaman yang sempurna terhadap roh syari'at Islam diharapkan dapat menjadi petunjuk yang hakiki dalam menyikapi segala kondisi. ${ }^{32}$

28 Imam al-Harran Ismail bin Muhammad al-Farra'.beliau memperdalam ilmu faraidh (ilmu waris) ilmu figh diperolehnya dari Abul Fath al-Ba'labaki dan ash-Shaffi al-Hindi. Ilmu Tafsir, ia menimba ilmu dari ulama terkemuka bernama Jamaluddin al-Mizzi. Dan Syaikhul Islam Taqiyuddin Ibn Taimiyah, darinya Ibnu Qayyim memperdalam berbagai keilmuan seperti: ilmu tafsir, figh, hadis, faraidh, ilmu ushul, ilmu kalam, dll

${ }_{29}$ Al-Jauziyah, Fawa-idul Fawa-id: Menyelami Samudra Hikmah dan Lautan Ilmu Menggapai Puncak Ketajaman

Batin Menuju Allah, 10.

${ }^{30}$ Al-Jauziyah, , 11-12.

${ }^{31}$ Al-Jauziyah, ,.

${ }^{32}$ Al-Jauziyah, 14 
Selepas itu, selama kurang lebih 16 tahun Ibnu Qayyim menimba serta memperdalam ilmu agama dengan gurunya yang bernama Ibnu Taimiyyah. ${ }^{33}$ Berkat kesungguhan dan ketekunannya dalam menuntut ilmu beliau termasuk salah seorang yang ahli dalam berbagai disiplin ilmu pengetahuan dan ilmu agama. ${ }^{34}$

Sepanjang sejarah riwayat hidup Ibnu Qayyim, para sejarawan ${ }^{35}$ memberikan penilaian yang baik terhadapnya. Sejarah mencatat bahwa dari sejak kecil sampai dewasa beliau dikenal dengan kapasitas intelektualnya yang tinggi sehingga memungkinkan beliau menjadi ulama panutan. Selain itu, pribadinya yang baik dan disukai semua orang serta keteguhannya dalam memegang ajaran agama. $^{36}$ Beliau pun mempunyai kepribadian yang baik dan berakhlak mulia serta ahli ibadah. Dengan begitu, Ibnu Qayyim Al-Jauziyah dijuluki sebagai lautan ilmu dengan berbagai ragamnya, disebabkan karena beliau ahli dalam memahami al-Kitab dan as-Sunah, serta disiplin ilmu lainnya. ${ }^{37}$ Beliau menempati posisi sebagai ulama yang cerdas dan disegani di zamannya. ${ }^{38}$

Bersama gurunya (Ibnu Taimiyyah), Ibnu Qayyim berhasil mengembalikan keagungan dan keindahan Sunah dan membersihkan segala sesuatu yang mengotori kemurnian ajaran-Nya. Sampai pada suatu ketika selama beberapa tahun mereka mendekam di penjara dan adanya tindakan penyiksaan yang menyakitkan

33 Al-Jauziyah, Hanya Untukmu Anakku, Panduan Lengkap Pendidikan Anak Sejak dalam Kandungan Hingga Dewasa., 16-17

${ }^{34}$ Al-Jauziyah,,20

35 Aud Allah Jar Hijazi dan Bakr ibn Abdullah Abu Zaid.

36 Baktiar Nasution, "Konsep Pendidikan Islam

Menurut Ibn Qayyim: Relevansinya Dengan Pendidikan Modern, " Tesis, 2011., 138

37 Al-Jauziyah, Fawa-idul Fawa-id: Menyelami Samudra Hikmah dan Lautan Ilmu Menggapai Puncak Ketajaman Batin Menuju Allah., 10

38 Muhaemin, "Konsep Pendidikan Ibn Qayyim AlJauziyah. , 8 dari orang-orang yang fanatik dan taklid yang disebabkan karena keduanya berpendapat terhadap beberapa masalah. ${ }^{39}$ Akan tetapi, selama berada di dalam penjara, beliau menyibukkan diri dengan membaca Alquran disertai dengan tafakur dan tadabur (berkontemplasi dan berfikir). Sampai akhirnya Allah Swt. membuka pintu kebaikan yang sangat lebar padanya dan mendapatkan hikmah. ${ }^{40}$ Beliau mendapatkan ketajaman intuisi, kepribadian dan jiwa yang benar dan sehat. ${ }^{41}$ Juga memperoleh insting dan perasaan yang lurus. Berawal dari sana, beliau mempunyai kemampuan yang luar biasa untuk berbicara tentang ilmu tasawuf dan menyelami samuderanya yang dalam, menguasai ilmu orang-orang ahli ma'rifat kemudian membicarakannya dengan berbagai kemusykilannya. ${ }^{42}$ Beliau baru bisa dibebaskan setelah Ibnu Taimiyah meninggal dunia. ${ }^{43}$ Lamanya Ibnu Qayyim mulazamah (menemani dengan lekat) dengan Ibnu Taimiyah, pemikirannya pun banyak dipengaruhi olehnya. ${ }^{44}$

Ibnu Qayyim lebih dikenal sebagai cendekiawan muslim yang reformis dibandingkan sebagai seorang sufi. Ibnu Qayyim Al-Jauziyah dikenal pula sebagai penulis berkarya dalam bidang keilmuan (masalah fiqih, , ilmu mantiq usul fiqh serta berbagai disiplin pemikiran Islam) yang tergolong dalam kategori rujukan utama. Tidak heran bahwa Ibnu Qayyim memiliki banyak karya baik itu di bidang sirah

\footnotetext{
${ }^{39}$ Salah satunya Ibn Qayyim pernah menentang orang yang berwisata ke kuburan al-Khalil Ibrahim. Lihat

Ibnu Qayyim Al-Juziyah, Managemen Qalbu, Melumpuhkan Senjata Syetan, (Jakarta: PT Darul Falah, 2005).

${ }^{40}$ Abdul Hafidz, Tasawuf Dalam Pandangan Ulama Salaf (Jakarta Timur: Pustaka Al-Kautsar, 2001)., 20

41 Nasution, "Konsep Pendidikan Islam Menurut Ibn Qayyim: Relevansinya Dengan Pendidikan Modern.", 137

${ }^{42}$ Al-Juziyah, Managemen Qalbu, Melumpuhkan Senjata Syetan.

${ }^{43}$ Syukur Yakub, “Konsep Pendidikan Anak Usia Dini Menurut Ibnu Qayyim Al-Jauziyah, ”Skripsi, 2013., 34

44 Ulin Na'mah, "Ibn Qayyim Al-Jauziah dan Pendapatnya tentang Tradisi Kalam," Universum 9, no. 1 (2015)., 68
} 
(biografi), fiqih, tawasuf, ushul, ilmu kalam, dan sejarah, dll. dari banyak karyanya $^{45}$ diantara karya-karya Ibnu Qayyim Al-Jauziyah yang cukup terkenal adalah sebagai berikut.

1. Tuhfah al-Maudud, fi Ahkam alMaulud, diterjemahkan ke dalam Bahasa Indonesia dengan judul "Hanya Untukmu Anakku: Panduan Lengkap Pendidikan Anak Sejak dalam Kandungan hingga Dewasa" kitab ini yang menjelaskan tentang pendidikan dan psikologi anak. Karya ini sebagai hadiah atas kelahiran anaknya. Secara garis besar memuat tentang hukumhukum yang berkaitan dengan bayi yang baru lahir serta perjalanan manusia sejak masih berbentuk nutfah (cairan) sampai masuknya surga dan neraka. Kitab ini yang saya jadikan sebagai sumber primer dari penelitian ini.

2. Miftah Dar as Sa'adah, diterjemahkan ke dalam Bahasa Indonesia dengan judul "Kunci Kebahagiaan" terbitan tahun 2004, secara umum kitab ini memuat keutamaan ilmu, pembinaan rohani, serta berbagai macam hikmah. ${ }^{46}$ Menerangkan secara jelas tentang ilmu dan kehendak serta kedudukannya, ilmu dan keutamaannya, serta kebutuhan manusia terhadap ilmu yang menjadi tanda kesempurnaannya. ${ }^{47}$

3. Madarijus Salikin Baina Manjil Iyyaka Na 'budu wa Iyyaka Nasta'in.

Karya ini sangat monumental dalam kajian tasawuf, yang telah dialih bahasakan kedalam bahasa indonesia dengan judul: Madarijus Salikin: Jenjang Spiritual Para Penempuh Jalan Ruhani. Pada tahun 1998.

45 Kurang lebih ditemukan 97 karya dalam berbagai bidang keilmuan

46 Muhaemin, "Konsep Pendidikan Ibn Qayyim AlJauziyah.", 7

47 Nasution, "Konsep Pendidikan Islam Menurut Ibn Qayyim: Relevansinya Dengan Pendidikan Modern.”, 7
Memuat tentang cara cetak akhlak dan jiwa yang baik dan bersih jiwanya, jujur, bersih jiwanya, dan bersinar hatinya dengan hidayah Allah.

4. Zadul Ma'ad Fi Hadyi Khairil 'Ibad. Karya ini sudah dialih bahasakan oleh Kathur Sukardi ke dalam bahasa Indonesia dengan judul: Zadul Ma'ad: Bekal Perjalanan ke Akhirat. secara umum buku ini tergolong ke dalam kajian fiqh dan akhlak Tasawuf. ${ }^{48}$ disebut sebagai sebuah karya ensiklopedia yang di dalamnya terdapat berbagai disiplin ilmu, seperti: selekta dalam tafsir dan hadis, tauhid, ilmu kalam, sirah, fiqh, nahwu dan yang lainnya. $^{49}$

5. Ar-Ruh. Karya ini sudah dialih bahasakan ke dalam bahasa indonesia yang diterbitkan oleh penerbit pustaka Al-kautsar Jakarta pada tahun 2000 dengan judul Roh, buku ini cenderung bernuansa teologi eskatologis. Cetakan keduanya pada tahun 1982 oleh Darul Fikr, Beirut, Libanon

6. Ad-Daa' wa Ad-Dawaa' atau alJawabul Kafi Liman saala 'an adDawaa' as-Syafii, kitab ini merupakan pemikiran Ibnu Qayyim yang bermula dari pertanyaan-pertanyaan yang diajukan kepadanya, serta berisi tentang manfaat ilmu serta muhasabah dan pengendalian jiwa.

7. Al-Thibb al-Nabawi, (Pengobatan cara Nabi), kitab ini dijadikan pedoman dalam jasmani karena memfokuskan pada masalah seksual dan kesehatan.

Tingginya kapasitas intelektual Ibnu Qayyim membuat karya-karyanya menduduki tempat istimewa serta respon yang baik di antara kalangan ulama-ulama lainnya. Selain itu, karya beliau juga dianggap sebagai salah satu referensi yang mampu mengintegrasikan antara aql (akal)

\footnotetext{
${ }^{48}$ Hernawan, "Posisi Ruh Dalam Realitas Menurut Ibnu Qayim Al-Jauziyah.”, 81

${ }^{49}$ Yakub, "Konsep Pendidikan Anak Usia Dini Menurut Ibnu Qayyim Al-Jauziyah. ”, 36
} 
dan naql (sumber Alquran dan Hadis), kemudian pemikirannya yang berpegang teguh pada manhaj salafush sahalih.

Secara umum, pemikiran Ibnu Qayyim berlandasakan pada dalil yang kuat. Keseluruhan pembahasan didalam pemikirannya cenderung berladaskan pada dalil yang benar dan ungkapkan secara inshaf__ (adil dan berimbang). ${ }^{51}$ Dalam berfikir pun, beliau menyerukan kebebasannya, namun tetap berpegang teguh pada ajaran Islam dan aqidah salafush shalihin. ${ }^{52}$

Karakteristik pemikiran Ibnu Qayyim sangat mendalam, argumentatif serta konsisten. Hal itu dapat dibuktikan dari cara beliau yang sangat teliti menganalisa terhadap suatu permasalahan sampai pada ke akar masalah dengan melakukan pelacakan pada analisa terdahulu. Pemikiran yang dihasilkannya senantiasa merujuk pada syar'i dan penalaran secara terpadu sehingga argumen pemikirannya masih sangat mendasar. Kemudian kemampuan dalam mensosialisasikan hasil pemikirannya, walaupun hasilnya bertentangan dengan pendapat umum yang tersebar di masyarakat sekitar. Hal itu menunjukkan kekonsistenannya dalam berfikir. $^{53}$

Dalam menyimpulkan sumber hukum, Ibnu Qayyim mengambil sumber-sumber yang menjadi acuannya ialah berlandaskan al-Kitab dan as-Sunah serta ijma'. ${ }^{54}$ Kemudian fatwa Sahabat, ${ }^{55}$ fatwa para tabi'in (generasi setelah sahabat), lalu fatwa tabi'ut tabi'in (generasi setelah tabi'in). Setelah semua fatwa dianalisis baru kemudian beranjak kepada qiyas (analogi dengan hukum yang sudah ada), istishab (berpegang pada hukum sebelumnya), mashlahah (tinjauan maslahat serta mudharat), saddudz dzari'ah (tindakan preventif), dan 'urf (kebiasaan masyarakat). ${ }^{56}$

Ibnu Qayyim memandang bahwa Islam membangun konsep dalam kehidupan atas dasar Iman, Islam, dan Ihsan. ${ }^{57}$ Beliau berusaha menempatkan ketiganya (Iman, Islam, dan Ihsan) secara sinergi dalam kesetaraan serta keharmonisan dengan tujuan untuk mengantarkan umat manusia pada kebahagiaan hidup yang hakiki. ${ }^{58}$

Ketika beliau mengemukakan pendapatnya, beliau tidak langsung serta merta menjelaskannya. Pada awalnya beliau akan menelaah berbagai konsep golongan yang lain, selanjutnya akan didalami secara komprehnsif. Dengan itu beliau memiliki tujuan menegakkan kebenaran dan meleyepkan kebatilan. ${ }^{59}$ Dan ketika ia menerangkannya, ia menggunakan metode yang benar-benar baru, siapapun belum perna menggunakannya dengan memaparkan dalilnya. ${ }^{60}$

Maka dari itu, madzhab Ibnu Qayyim berdiri berlandaskan pada prinsip ittiba' (mengikuti). Bukan madzhab fanatik dan tanpa menyekat dirinya dengan aliran madzab yang lain meskipun bila di awal diungkapkan bahwa beliau bermadzab

50 Baktiar Nasution, “Konsep Pendidikan Islam Menurut Ibn Qayyim: Relevansinya Dengan Pendidikan Modern," 2011., 138

51 Al-Jauziyah, Hanya Untukmu Anakku, Panduan lengkap pendidikan anak sejak dalam kandungan hingga dewasa, 18.

52 Basri, "Ibnu Qayyim Al-jauziyah tentang Pengaruh Perubahan Sosial.”, 195-196

53 Muhammad Badawi, "Transformasi Hukum Islam dalam Kerangka Berfikir Ibnu Qayyim Al-Jauziyah," n.d., 2.

${ }^{54}$ Yang tidak diketahui bahwa terdapat pendapat lain yang menyelisihinya.

55 Selama tidak ada pendapat lain yang berseberangan dengannya, jika hal itu terjadi, maka menganalisis kembali dan menentukan pilihan.

${ }^{56}$ Al-Jauziyah, Fawa-idul Fawa-id: Menyelami Samudra Hikmah dan Lautan Ilmu Menggapai Puncak Ketajaman Batin Menuju Allah., 13

57 Arikhah, "Reaktualisasi Pemikiran Ibn Qayyim AlJauziyyah dalam Pengembangan Tasawuf.", 74

58 Arikhah, "Reaktualisasi Pemikiran Ibn Qayyim ALjauziyah dalam Pengembangan Tasawuf", 77

59 Al-Jauziyah, Fawa-idul Fawa-id: Menyelami samudra hikmah dan lautan ilmu menggapai puncak ketajaman batin menuju Allah, 11.

60 Al-Jauziyah, Hanya Untukmu Anakku, Panduan lengkap pendidikan anak sejak dalam kandungan hingga dewasa, 18. 
Hambali tetapi beliau tidak memihak, akan tetapi beliau berlandaskan dalil yang kuat. $^{61}$

Madzhabnya berlandaskan kebenaran berfikirnya, tidak berlandaskan emosional ataupun bahkan alirannya. Upaya tersebut bertujuan untuk meluruskan yang taklid buta terhadap semua hal serta keseriusannya dan kegigihannya dalam mengungkapkan kebenaran berdasarkan al-Quran dan Sunnah disamping memiliki tujuan untuk meluruskan takwil-takwil yang mengikuti hawa nafsu dan maknanya dikembalikan kepada Allah Swt.. ${ }^{62}$ Menurutnya, segala bentuk amaliah tidak bersifat logis jika tidak didasarkan pada Alquran dan al-Hadis. Apalagi jika digunakan dalam mendekatkan diri pada Allah ketika syari'at tidak dilaksanakan. ${ }^{63}$ Pemikirannya yang gamblang, perhatian Ibnu Qayyim dalam membangkitkan kembali umat Islam yang sedang tertidur dengan memerangi taklid buta, khurafat, bid'ah, berusaha melakukan terobosan baru pada ajaran tasawuf, serta menghidupkan tauhid sebagai metodenya agar kembali pada ajaran yang diserukan di dalam Alquran dan al-Hadis.

Ibnu Qayyim al-Jauziyah wafat pada tanggal 23 Rajab $751 \mathrm{H}^{64}$ atau $1350 \mathrm{M}$. Ada pula yang berpendapat bahwa beliau wafat malam Kamis 13 Rajab tepatnya ba'da Isya. Beliau dishalatkan di Masjid Agung Damaskus keesokan hari setelah beliau wafat dan kemudian di Masjid AlJarrah dekat tempat ia dimakamkan dan dikebumikan ba'da dzuhur di pemakaman Baabush Shaghiir di Damaskus. Dalam usia 60 tahun beliau wafat, dan ada pula yang berpendapat bahwa beliau wafat pada usia 64 tahun. ${ }^{65}$

\section{Pendidikan Anak Perspektif Sufistik dalam Pandangan Ibnu Qayyim Al- Jauziyah}

Prinsip dasar tentang pendidikan dalam pandangan Ibnu Qayyim Al-Jauziyah yaitu tidak lain bersumber daripada ayat Alquran yakni:

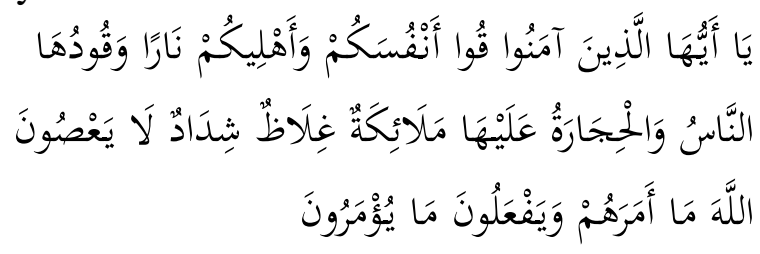

Artinya: "Hai orang-orang yang beriman, peliharalah dirimu dan keluargamu dari api neraka yang bahan bakarnya adalah manusia dan batu ...." (QS. At-Tahrim: 6)

Pendidikan dalam pandangan Ibnu Qayyim, secara Bahasa diambil dari tiga kata yaitu, rabb yang berarti memiliki, majikan, guru, pendidik, yang menegakkan, yang memberi nikmat, yang mengurus, dan yang memperbaiki. Kemudian kata rabbany yang berarti 'alim yang mengajar, yang memberi pengetahuan, dan ilmu yang besar manfa'atnya. Kemudian tarbiyah yang berarti mendidik, merawat, menumbuhkan, memiliki, memper-baiki, dan menguatkan. ${ }^{66}$

Dari ayat di atas, Ibnu Qayyim berpendapat dengan mengikuti penafsiran Imam Ali yang menafsirkan khusus pada kalimat perintah di atas "peliharalah" yaitu dengan perkataan "Ajarilah mereka dan didiklah mereka". ${ }^{67}$ Dari perkataan Imam Ali tersebut penulis menyimpulkan hal tersebut menunjukkan bahwa adanya

61 Al-Jauziyah, Hanya Untukmu Anakku, Panduan lengkap pendidikan anak sejak dalam kandungan hingga dewasa, 18.

62 Al-Jauziyah, Fawa-idul Fawa-id: Menyelami samudra hikmah dan lautan ilmu menggapai puncak ketajaman batin menuju Allah, 11.

${ }^{63}$ Arikhah, "Reaktualisasi Pemikiran Ibn Qayyim AlJauziyyah dalam Pengembangan Tasawuf.", 76

${ }^{64}$ Ibnu Qayyim Al-Jauziyah, Hanya Untukmu Anakku, Panduan lengkap pendidikan anak sejak dalam kandungan hingga dewasa, 24.

${ }^{65}$ Ibnu Qayyim Al-Jauziyah, Cerdas ala Rasulullah Saw., 5.

${ }^{66}$ Ridwan, "Pendidikan Karakter Menurut Perspektif Imam Ibnu Qayyim Al-Jauziyah," Jurnal Studi Islam 1, no. 2 (2016)., 9

67 Al-Jauziyah, Hanya Untukmu Anakku, Panduan Lengkap Pendidikan Anak Sejak dalam Kandungan Hingga Dewasa., 415 
kewajiban orangtua dalam memberikan pendidikan dan pengajaran kepada anaknya.

Ibnu Qayyim mendefinisikan tarbiyah secara etimologi ialah sebagai suatu usaha yang dilakukan oleh pendidik dalam mendidik manusia (anak) dengan ilmunya yang bertujuan agar terbentuknya kepribadian yang taat kepada Allah Swt., berakhlak mulia, berilmu, dan sehat dari segi jasmani maupun rohani. ${ }^{68}$

Dengan demikian, Ibnu Qayyim menyebutkan bahwa pendidikan adalah tanggung jawab orang tua, guru, dan pemerintah. Hal tersebut dikarenakan pendidikan merupakan bimbingan urusan anak. Dalam hal ini harus adanya perlakuan yang baik terhadapnya, seperti membina dan merawat dengan baik serta mengarahkannya pada hal yang positif secara perlahan sebagai bahan pembelajaran di masa selanjutnya. Selain itu, menumbuh-kembangkan kemampuan mereka sampai ia mencapai kesempurnaan untuk kemaslahatan dirinya supaya ia bisa menjawab setiap persoalan baik kecil maupun besar yang menimpanya di masa yang akan datang. ${ }^{69}$

Dalam hal pendidikan, Ibnu Qayyim memberikan perhatian penuh terhadapnya, terbukti dengan adanya asumsi bahwa Ibnu Qayyim menempatkan pendidikan anak menjadi tema yang paling sentral di dalam pemikirannya tentang pendidikan. ${ }^{70}$ Pendidikan dalam pandangan Ibnu Qayyim mencakup dua sekaligus yaitu pendidikan jasmani dan rohani $^{71}$ atau dengan kata lain pendidikan hati (qalb)

68 Imron Rossidy, “Analisis Komparatif tentang Pendidikan Anak Menurut Ibn Qayyim Al-Jauziyah dan Al-Ghazali: Implikasinya Terhadap Pendidikan Agama Islam Kontemporer," nitro Professional, n.d.,4

69 Ridwan, "Pendidikan Karakter Menurut Perspektif Imam Ibnu Qayyim AL-Jauziyah., ,9

${ }_{70}$ Rossidy, "Analisis Komparatif tentang Pendidikan Anak Menurut Ibn Qayyim Al-Jauziyah dan Al-Ghazali: Implikasinya Terhadap Pendidikan Agama Islam Kontemporer..

${ }^{71}$ Muhaemin, “Konsep Pendidikan Ibn Qayyim AlJauziyah.”, 12 dan pendidikan badan sekaligus. ${ }^{72}$ Dengan demikian, dapat disimpulkan bahwa setiap manusia bukan hanya memerlukan pendidikan fisik saja melainkan semua manusia membu-tuhkan pendidikan psikis dan psikologis yang harus dipenuhinya.

Tugas utama dalam sebuah pendidikan ialah membentuk pribadi yang bermoral dengan capaian memiliki kemampuan dalam mengelola hidupnya di dunia sesuai dengan kaidah syari' at yang benar. ${ }^{73}$ Dalam hal ini, tujuan pendidikan menurut Ibnu Qayyim ialah menum-buhkembangkan seluruh potensi yang dimiliki anak, memelihara fitrahnya, menjaganya dari perbuatan tercela serta menanamkan kesadaran akan ibadah kepada Allah Swt. sampai ia mampu merealisasikannya dalam perbuatannya sehari-hari. ${ }^{74}$

Pendidikan dalam pandangan Ibnu Qayyim, ditekankan harus adanya perhatian secara khusus dan terfokus terhadap aspekaspek pendidikan yang mengacu pada seluruh potensi yang ada pada diri manusia. ${ }^{75}$ Oleh karena itu, Ibnu Qayyim memfokuskan pendidikan anak ke dalam beberapa aspek. Aspek-aspek pendidikan anak yang menjadi perhatian Ibnu Qayyim, antara lain. $^{76}$

1. Tarbiyah Fikriyah (Pendidikan Akal)

2. Tarbiyah Athifiyah (Pendidikan Perasaan)

3. Tarbiyah Khuluqiyah (Pendidikan Akhlak)

4. Tarbiyah Ijtima'iyah (Pendidikan Kemasyarakatan)

72 Nasution, "Konsep Pendidikan Islam Menurut Ibn Qayyim: Relevansinya Dengan Pendidikan Modern.”, 141

${ }^{73}$ Abdullah, "Pendidikan Prenatal: Telaah Pemikiran Ibn Qayyim Al-Jauziyah dalam Kitab Tuhfah Al-Maudud bi Ahkam Al-Maulud dan Relevansinya dengan Pendidikan Islam.", 342

74 Ridwan, "Pendidikan Karakter Menurut Perspektif Imam Ibnu Qayyim Al-Jauziyah", 10

${ }^{75}$ Ridwan, "Pendidikan Karakter Menurut Perspektif Imam Ibnu Qayyim Al-Jauziyah, 13

76 Rossidy, "Analisis Komparatif tentang Pendidikan Anak Menurut Ibn Qayyim Al-Jauziyah dan Al-Ghazali: Implikasinya Terhadap Pendidikan Agama Islam Kontemporer. ", 7 
5. Tarbiyah Iradah (Pendidikan Kehendak)

6. Tarbiyah Badaniyah (Pendidikan Badan)

7. Tarbiyah Jinsiyah (Pendidikan Seks) ${ }^{77}$

Pendidikan menurut Ibnu Qayyim merupakan suatu keharusan yang harus sudah dilakukan sejak usia dini dengan seksama dan kesabaran serta orangtua harus mengetahui setiap kebutuhan anak pada setiap fase pertumbuhannya. ${ }^{78} \mathrm{Hal}$ yang paling diutamakan ialah masalah pendidikan akhlak, karena di setiap pendidikan yang diberikan orangtua pada anaknya akan membekas dalam memori anak sampai si anak mencapai usia dewasa. ${ }^{79}$ Hal itu disebabkan karena pada periode itu (sejak dini) kemampuan otak dan saraf sudah siap dalam menerima pengaruh. Jadi, setiap apa yang dilihat dan didengarnya akan memengaruhi otak, saraf, serta jiwa anak. ${ }^{80}$ Maka dari itu, jika orangtua membiarkan anaknya tanpa diberikan pendidikan yang bermanfaat bagi anak itu adalah suatu kehancuran yang sangat besar. Kurangnya perhatian orangtua ter-hadap anak akan mendayagunakan dirinya sendiri terlebih tidak akan memberi manfaat pula pada orangtuanya sendiri, lebih jauh lagi si anak akan sulit dalam menjalankan kewajiban dan perintah agama. ${ }^{81}$

Urgensi tasawuf sangat dibutuhkan di semua bidang kehidupan, terutama dalam kehidupan keluarga, karena pendidikan keluarga dapat diandalkan sebagai lembaga ketahanan untuk mewujudkan manusia yang memiliki moralitas, dalam upaya menjaga agar keluarga tetap menjadi lembaga ketahanan akhlak.82 Oleh karena itu, pendidikan anak perspektif sufistik dalam proses mendidiknya mengajarkan nilai-nilai sufistik. ${ }^{83}$ Dalam pandangan Ibnu Qayyim Al-Jauziyah pendidikan sufistik berarti memberikan pengajaran dan pelatihan kepada anak supaya anak tidak mencintai dunianya yang didorong oleh keinginan hawa nafsu. Dalam memaknai kata tarbiyah, beliau menyebutkan sebagai suatu tindakan seorang guru yang berusaha mengoreksi serta mengeluarkan semua akhlak-akhlak tercela yang terdapat di dalam diri anak didik kemudian akhlak tercela tersebut digantinya dengan akhlak terpuji sehingga anak tersebut akan tumbuh menjadi pribadi yang baik, berakhlakul karimah, serta mengarahkan dan membimbingnya menuju jalan Allah Swt. supaya ia mendekat diri kepada-Nya. ${ }^{84}$

\section{Metode Mendidik Anak Perspektif Sufistik dalam Pandangan Ibnu Qayyim Al-Jauziyah}

Metode yang paling penting dalam mendidik anak ialah seorang ibu harus memiliki kesabaran yang luar biasa dalam mendidik anak, terlebih pada masa menyusui anaknya, itulah bentuk kasih sayang ibu yang tidak terbatas. ${ }^{85}$

Sebagaimana telah dijelaskan sebelumnya bahwa pendidikan dalam pandangan Ibnu Qayyim Al-Jauziyah mencakup pendidikan jasmani sekaligus pendidikan ruhani atau dengan kata lain pendidikan badan dan pendidikan hati. Dalam ungkapannya, Ibnu Qayyim pun

77 Rossidy, “Analisis Komparatif tentang Pendidikan Anak Menurut Ibn Qayyim Al-Jauziyah dan Al-Ghazali: Implikasinya Terhadap Pendidikan Agama Islam Kontemporer.,",7

${ }^{78}$ Yakub, "Konsep Pendidikan Anak Usia Dini Menurut Ibnu Qayyim Al-Jauziyah.”, 37

${ }^{79}$ Yakub, "Konsep Pendidikan Anak Usia Dini Menurut Ibnu Qayyim Al-Jauziyah”., 38

${ }^{80}$ Amini, asupan iahi agar tak salah mendidik amanatNya 1, 218.

${ }^{81}$ Rachman, Islamic Teen Parenting, 4.

82 Jalaluddiin Rakhmat dan Muhtar Gandaatmaja, keluarga Muslim dalam Masayarakat Modern (Bandung: PT. Remaja Rosdakarya, 1994), 3.

83 sifat-sifat mulia yang dimiliki kaum sufi.

84 Rossidy, "Analisis Komparatif tentang Pendidikan Anak Menurut Ibn Qayyim Al-Jauziyah dan Al-Ghazali: Implikasinya Terhadap Pendidikan Agama Islam Kontemporer. ", 5

85 Ahmad Hadi Yasin, Dahsyatnya Sabar (Jakarta Selatan: Qultum Media, 2012), 284. 
sekaligus menyebutkan cara untuk mendidiknya, yaitu: untuk menumbuhkembangkan dalam pendidikan badan dan hati agar keduanya mampu tumbuh dengan sempurna serta lebih baik dari sebelumnya. Pertama, sehatnya badan dengan cara diberi gizi yang baik serta harus dijaga dan dilindungi dari segala hal yang mengancam keselamatan dan kesehatannya. Begitu juga dengan hati, jika ingin tumbuh menjadi lebih baik dan bersih, hati juga memerlukan gizi yang baik dan menyehatkan ${ }^{86}$ dan dilindungi dari hal yang membuatnya sakit. Tidak ada resep manjur yang dapat menyehatkan hati serta dapat mengantarkannya pada kesempurna-an fitrah, kecuali dengan

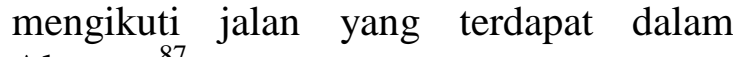
Alquran. ${ }^{87}$

Perhatian pendidikan dalam pandangan Ibnu Qayyim sebenarnya sudah dimulai pada masa perkembangan selama berada dalam kandungan. Menurut pandangannya, janin pada saat di dalam kandungan sudah dianugerahi berupa daya pendengaran, penglihatan, dan hati, dan ketiganya sudah mulai berfungsi sehingga janin di dalam kandungan sudah mampu untuk berinteraksi dengan keadaan internal maupun eksternal. Pada kenyataan itu, pendidikan sudah dapat diterapkan (diberikan) terhadap anak. ${ }^{88}$ Menurutnya, pada fase ini akan sangat membantu dalam memengaruhi pertumbuhan anak di masa setelah anak dilahirkan.

Berdasarkan pendapat Ibnu Qayyim yang senada dengan pendapatnya AlGhazali. Keduanya menganjurkan dalam menerapkan metode pendidikan pada anak yang beragam. Akan tetapi keberagaman tersebut tetap sesuai dengan tingkat

${ }^{86}$ Salahsatu gizi yang baik untuk hati ialah selalu ingat kepada Allah.

87 Muhaemin, "Konsep Pendidikan Ibn Qayyim AlJauziyah.", 13

${ }^{88}$ Abdullah, "Pendidikan Prenatal: Telaah Pemikiran Ibn Qayyim Al-Jauziyah dalam Kitab Tuhfah AlMaudud bi Ahkam Al-Maulud dan Relevansinya dengan Pendidikan Islam.”, 349 perkembangan anak. Kemudian, untuk membentuk perilaku anak, pembinaan budi pekerti dan penanaman sifat-sifat mulia pada diri anak, keduanya sangat menekankan pada metode keteladanan. Yaitu teladan yang baik yang harus ditunjukkan orang tua dalam mendidik anak. Orang tua harus menjadikan dirinya seorang yang istiqomah dan terpuji akhlaknya. Karena seorang anak akan meniru perilaku yang ditunjukkan orang tuanya baik itu perbuatan terpuji atau tercela. ${ }^{89}$

Selanjutnya, Ibnu Qayyim juga menekankan menggunakan metode pelatihan dan pembiasaan sejak kecil terhadap perilaku baik yang bermanfaat untuk anak. Salahsatunya bisa dengan cara menyertakan anak dalam setiap perbuatan baik yang akan orang tua lakukan, mengisi waktu luangnya dengan sesuatu yang bermanfaat. Tapi, hal yang paling penting ialah menjauhkannya dari sifat malas. Hal tersebut bertujuan agar apa yang telah dibiasakannya sejak kecil akan menjadi kebiasaannya di waktu anak dewasa yang tidak akan ditinggalkannya. ${ }^{90}$

Pada masa perkembangan akhlak anak, sangat dibutuhkan perhatian ekstra dari orang tua agar anak tumbuh berkembang dengan pembiasaan diri berbuat baik sejak kecilnya dengan melakukan perintahperintah Allah Swt. ${ }^{91}$ Salah satunya, sebagai bentuk pendidikan akhlak untuk anak ialah sebaiknya anak tidak diberi makanan dengan jumlah yang banyak sehingga membuat anak menjadi kekenyangan. Jangan paksa atau biarkan anak banyak makan dan minum, karena ketika perutnya penuh dengan makanan (kekenyangan) akan

\footnotetext{
89 Rossidy, "Analisis Komparatif tentang Pendidikan Anak Menurut Ibn Qayyim Al-Jauziyah dan Al-Ghazali: Implikasinya Terhadap Pendidikan Agama Islam Kontemporer. ", 9

${ }^{90}$ Rossidy, "Analisis Komparatif tentang Pendidikan Anak Menurut Ibnu Qayyim Al-jauziyah dan Al-Ghazali, Implikasinya Terhadap Pendidikan islam Kontemporer", 9

91 Yakub, “Konsep Pendidikan Anak Usia Dini Menurut Ibnu Qayyim Al-Jauziyah.", 51
} 
memberatkan anak melakukan sesuatu (malas), dan menyebabkan banyak tidur, sedangkan dengan banyaknya tidur akan mengakibatkan hati menjadi keras. ${ }^{92}$

Selanjutnya, hindari anak banyak bergaul dengan orang yang kurang baik tingkah lakunya yang secara langsung maupun tidak langsung hal tersebut memungkinkan akan sangat berpengaruh terhadap perkembangan akhlak anak.

kemudian, biasakan anak dengan sifat suka memberi, ajarkan bahwa segala sesuatu yang ia miliki adalah bukan seutuhnya miliknya supaya ia tidak mencintai dan tidak bergantung pada sesuatu yang di milikinya. ${ }^{94}$

Segala bentuk pendidikan (pengajaran dan pelatihan) yang telah disebutkan di atas, menurut Ibnu Qayyim termasuk ke dalam riyadhah (latihan). Riyadhah artinya melatih jiwa untuk menerima kebenaran. Riyadhah (latihan) dapat diartikan dengan mendidik akhlak dengan ilmu, membersihkan amal dengan keikhlasan, serta memperbanyak hak dengan mu'amalah. Mendidik akhlak dengan ilmu yaitu menata dan membersihkan akhlak sesuai dengan pranata ilmu, sehingga seorang hamba tidak akan bergerak baik dzahir maupun batin kecuali dengan ilmu, serta semua perbuatannya selalu ditimbang dengan timbangan syari'at. ${ }^{95}$

Mujahadah (sungguh-sungguh) adalah langka awal dalam proses penyucian jiwa menurut Ibnu Qayyim Al-Jauziyah, dengan melakukan tahapan-tahapan sesuai dengan arahan guru. Seorang salik akan terbiasa melakukannya sehingga nantinya

92 pada intinya, jauhkanlah anak dari sesuatu yang berlebih-lebihan.

${ }^{93}$ Ibnu Qayyim Al-Jauziyah, Hanya Untukmu Anakku, Panduan Lengkap Pendidikan Anak Sejak Dalam Kandungan Hingga Dewasa, 449-450.

94 Al-Jauziyah, Hanya Untukmu Anakku, Panduan Lengkap Pendidikan Anak Sejak dalam Kandungan Hingga Dewasa, 446-448.

${ }_{95}$ Al-Jauziyah, Madarijus Salikin, Pendakian Menuju Allah, 158. akan mengakar dan dapat mensucikan segala macam noda dan penyakit hati. ${ }^{96}$

Terdapat tiga maqamat menurut Ibnu Qayyim Al-Jauziyah, yaitu:

1. yaqzah (kesadaran).

2. Tafkir (berfikir)

3. bashiroh. Atau musyahadah (penyaksian)

Tahapan-tahapan itu merupakan proses tazkiyatun nafs yang diawali dengan takhalli (membersikan diri dari segala bentuk akhlak tercela yang dapat menimbulkan penyakit hati), kemudian dengan tahalli ( yakni menghiasi diri dengan akhlak terpuji sehingga hati menjadi bersih dari akhlak tercela selanjutnya akan tergantikan dengan sifat-sifat terpuji), tahap akhirnya, sampailah hati itu siap menerima cahaya pancaran ilahi (tajalli) yang membuatnya mampu melihat hakikat sesungguhnya.

\section{Implikasi Pendidikan Anak Perspektif Sufistik dalam Pandangan Ibnu Qayyim AL-Jauziyah}

Pendidikan yang dibiasakan orangtua sejak dini pada anaknya. Hal tersebut akan membuat anak terbiasa dengan perilaku baik dan ketika ia tumbuh besar anak sudah mengetahui perintah-perintah Allah Swt. dan akan terbiasa dalam melakukannya (menunaikan kewajiban perintah Allah Swt.). ${ }^{97}$ Jika anak terbiasa dengan perilaku terpuji yang ia terbiasa sejak usia dini, dan perilaku itu berlanjut dalam periode waktu yang lebih lama sampai anak remaja, dewasa, bahkan dalam masa pertumbuhan maka Allah Maha Tinggi. akan selalu menuntunnya menuju kesuksesan dan dia akan selalu tahu jalan kebajikan dan kebenaran yang mengantarkan mereka menuju tujuan. ${ }^{98}$

Maka pendidikan anak perspektif sufistik dalam pandangan Ibnu Qayyim secara tidak langsung akan berimplikasi pula

${ }^{96}$ Azra, Ensiklopedi Tasawuf, jilid II, 796.

97 Yakub, "Konsep Pendidikan Anak Usia Dini Menurut Ibnu Qayyim Al-Jauziyah.”, 55

${ }^{98}$ Ibn Miskawaih, Menuju Kesempurnaan Akhlak, penterj. Helmi Hidayat (Bandung: Mizan, 1997), 60. 
pada masa dewasa anak yang akan memiliki banyak keutamaan dan memiliki sifat-sifat mulia yang merupakan ajaranajaran kaum seperti zuhud, sabar, tawakal, wara'. Karena ketika ajaran tasawuf yang termanifestasi dalam ilmu pengetahuan dikembangkan untuk memupuk keimanan. Hal tersebut akan menghasilkan sesuatu yang indah dalam segala bidang kehidupan. ${ }^{99}$ Termasuk keindahan tersebut ialah memiliki sifat-sifat mulia yang dimiliki para sufi.

\section{SIMPULAN}

Berdasarkan paparan di atas, dapat di tarik kesimpulan bahwa ternyata yang selama ini dikenal sebagai ahli fiqih, salah satu cendekiawan muslim bernama Ibnu Qayyim Al-Jauziyah. Beliau dikenal sebagai seorang figur ulama yang kharismatik serta mendalami di berbagai bidang keilmuan (Fiqih, Ushul Fiqh, Ilmu Kalam, Tasawuf, dan lain-lain). Menurut sebagian orang mengatakan bahwa beliau pun termasuk sebagai ahli sufi. Juga, Ia memiliki pemikiran tentang konsep pendidikan yang terkandung dalam pelbagai kitab yang di karangnya. Sebagai jawaban dari rumusan masalah dari penelitian ini adalah:

1) Pendidikan anak perspektif sufistik dalam pandangan Ibnu Qayyim AlJauziyah adalah suatu usaha mendidik baik jasmani maupun rohani anak dengan ilmu agar mampu menerima kebenaran, sebagai bentuk penanaman moral pada jiwa anak supaya berakhlakul karimah, serta memberikan pengajaran dan pelatihan agar anak tidak mencintai dunianya. Dengan tujuan membimbing manusia agar mereka memiliki kepribadian yang yang mementingkan keridhaan
Allah Swt. ${ }^{100}$ dari pada kesenangan nafsu syahwatnya.

2) Metode mendidik anak dalam perspektif sufistik menurut pandangan Ibnu Qayyim Al-Jauziyah yaitu dengan cara memperhatikan ahdaf-ahdaf (tujuan) yang ditetapkan atau kemukakannya. Ahdaf jasmani untuk menjaga kesehatan jasmani anak, ahdaf fikriyah untuk menjaga perkembangan akal agar menambah kekuatan akal di masa dewasanya. Ahdaf akhlakiyah untuk memelihara agar baik akhlaknya, serta ahdaf maslakiyah untuk mengetahui kemampuannya.

Metode pendidikan anak perspektif sufistik dilakukan dengan tiga tahap,

1. Tahap yaqzah (kesadaran) yaitu memberikan pemahaman dengan beragam cara yang disesuaikan dengan tahapan perkembangan anak,

2. Tahap tafkir (berfikir) maksudnya dengan keteladan untuk membina budi pekerti.

3. Tahap musyahadah (penyaksian), yaitu pelatihan serta pembiasaan sejak kecil sebagai bentuk riyadhoh (latihan) untuk melatih jiwa agar menerima kebenaran.

3) Pendidikan anak perspektif sufistik yang diasumsikan Ibnu Qayyim berimplikasi terhadap kebahagiaan anak di masa depannya (masa dewasa). Hal tersebut akan terealisasi dengan baik jika pendidikan anak dilakukan dengan baik sesuai dengan syari'at dan mengikuti tahapan perkembangan anak. Maka, ketika anak terbiasa dengan perilaku terpuji yang selalu dibiasakannya sejak dini maka kebiasaan itu akan terpatri dalam jiwa anak sehingga ketika menginjak dewasa.

Kemudian pada masa dewasa anak yang akan memiliki banyak keutamaan

\footnotetext{
99 Arikhah, "Reaktualisasi Pemikiran Ibn Qayyim AlJauziyyah dalam Pengembangan Tasawuf., , 85
}

${ }^{100}$ Kepribadian yang mendorong manusia agar senantiasa beribadah kepada-Nya serta menta'ati perintah-Nya. 
dan memiliki sifat-sifat mulia yang merupakan ajaran-ajaran kaum sufi seperti zuhud, sabar, tawakal, wara' dan lainnya.

\section{DAFTAR PUSTAKA}

Abdullah, Muhammad. "Pendidikan Prenatal: Telaah Pemikiran Ibn Qayyim Al-Jauziyah dalam Kitab Tuhfah AlMaudud bi Ahkam Al-Maulud dan Relevansinya dengan Pendidikan Islam." al-Murabbi 2, no. 2 (2017).

Al-Ghazali. Ihya 'Ulumuddin. Jakarta: Republika Penerbit, 2012.

Al-Jauziah, Ibnu Qayyim. Madarijus Salikin, Pendakian Menuju Allah. Jakarta Timur: Pustaka Al-Kautsar, 1998.

Al-Jauziyah, Ibnu Qayyim. Cerdas ala Rasulullah SAW. Jakarta: Pustaka Azzam, 2011.

- Hanya Untukmu Anakku, Panduan Lengkap Pendidikan Anak Sejak dalam Kandungan Hingga Dewasa. Jakarta: Pustaka Imam Asy-Syafi'i, 2012.

Al-Jauziyah, Syamsuddin Ibnu Qayyim.

Fawa-idul Fawa-id: Menyelami Samudra Hikmah dan Lautan Ilmu Menggapai Puncak Ketajaman Batin Menuju Allah. Jakarta: Pustaka Imam Asy-Syafi'i, 2016. Al-Juziyah, Ibnu Qayyim. Managemen Qalbu, Melumpuhkan Senjata Syetan. Jakarta: PT Darul Falah, 2005.

Amini, Ibrahim. asupan iahi agar tak salah mendidik amanat-Nya 1. jakarta: Al-Huda, 2011.

—. Asupan Ilahi agar tak salah mendidik amanat-Nya 3. jakarta: Nur AlHuda, 2011.

Arikhah. "Reaktualisasi Pemikiran Ibn Qayyim Al-Jauziyyah dalam Pengembangan Tasawuf." at-Taqaddum 8, no. 1 (2016): 73-89.

Azra, Azyumardi. Ensiklopedi Tasawuf. Bandung: Angkasa, 2008.

Badawi, Muhammad. "Transformasi Hukum Islam dalam Kerangka Berfikir Ibnu Qayyim Al-Jauziyah,” n.d., 1-16.

Baharuddin. Aktualisasi Psikologi Islami. Yogyakarta: Pustaka Pelajar, 2011.

Basri, Rusdaya. "Ibnu Qayyim Al-jauziyah tentang Pengaruh Perubahan Sosial." AlManahij IX, no. 2 (2015).

Farhadian, Reza. Menjadi Orangtua Pendidik. Jakarta: Al-Huda, 2005.

Gandaatmaja, Jalaluddiin Rakhmat dan Muhtar. keluarga Muslim dalam Masayarakat Modern. Bandung: PT. Remaja Rosdakarya, 1994.

Hafidz, Abdul. Tasawuf Dalam Pandangan Ulama Salaf. Jakarta Timur: Pustaka AlKautsar, 2001.

Hernawan, Wawan. "Posisi Ruh Dalam Realitas Menurut Inu Qayim Al-Jauziyah." Syifa al-Qulub 1 (2017).

Iqbal, Abu Muhammad. Konsep Pemikiran Al-Ghazali Tentang Pendidikan. Madiun, Jawa Timur: Jaya Star Nine, 2013.

Miskawaih, Ibn. Menuju kesempurnaan akhlak. Bandung: Mizan, 1997.

Muhaemin. "Konsep Pendidikan Ibn Qayyim Al-Jauziyah." Ulul Albab 13 (2011).

Na'mah, Ulin. "Ibn Qayyim Al-Jauziah dan Pendapatnya tentang Tradisi Kalam." Universum 9, no. 1 (2015).

Nasution, Baktiar. "Konsep Pendidikan Islam Menurut Ibn Qayyim : Relevansinya Dengan Pendidikan Modern.” Tesis, 2011.

Prof. Dr. Rosihon Anwar, M.Ag. Akhlak Tasawuf. Bandung: CV Pustaka Setia, 2010.

Rachman, M.Fauzi. Islamic Teen Parenting. Bandung: Erlangga, 2014.

Rakhmat, Jalaludin. Reformasi Sufistik. Bandung: Pustaka Hidayah, 1999.

Ridwan. "Pendidikan Karakter Menurut Perspektif Imam Ibnu Qayyim ALJauziyah." Jurnal Studi Islam 1, no. 2 (2016).

Rossidy, Imron. "Analisis Komparatif tentang Pendidikan Anak Menurut Ibn Qayyim Al-Jauziyah dan Al-Ghazali: Implikasinya Terhadap Pendidikan Agama Islam Kontemporer." nitro Professional, n.d., 1-13.

Shihab, M. Quraish. Tafsir Al-Mishbah. Jakarta Pusat: Lentera Hati, 2012.

Tasmara, K.H. Toto. Kecerdasan Ruhaniah. Jakarta: Gema Insani Press, 2003.

Yakub, Syukur. "Konsep Pendidikan Anak 
Usia Dini Menurut Ibnu Qayyim AlJauziyah.” Skripsi, 2013.

Yasin, Ahmad Hadi. Dahsyatnya Sabar.

Jakarta Selatan: Qultum Media, 2012. 